\title{
Effects of Canthaxanthin on Egg Production, Egg Quality, and Egg Yolk Color in Laying Hens
}

\author{
J. H. Cho ${ }^{1}$, Z. F. Zhang ${ }^{1} \&$ I. H. Kim ${ }^{1}$ \\ ${ }^{1}$ Department of Animal Resource \& Science, Dankook University, \#29 Anseodong, Cheonan, Choongnam, \\ Korea \\ Correspondence: I. H. Kim, Department of Animal Resource \& Science, Dankook University, \#29 Anseodong, \\ Cheonan, Choongnam, Korea. Tel: 82-41-550-3652. E-mail: inhokim@dankook.ac.kr
}

Received: October 9, 2012 Accepted: October 25, 2012 Online Published: December 14, 2012

doi:10.5539/jas.v5n1p269

URL: http://dx.doi.org/10.5539/jas.v5n1p269

\begin{abstract}
The effects of canthaxanthin (CTX) on egg production, (average daily feed intake) ADFI, egg quality, and yolk color compared with natural xanthophylls in feedstuffs in laying hens were studied in a 5-wk trial. A total of 280 36-wk-old ISA Brown layers were divided into the following 7 treatments: T1, negative control $(30 \%$ corn $+20 \%$ wheat); T2, diet with 50\% corn; T3, diet with 5\% DDGS; T4, diet with $10 \%$ DDGS; T5, T1 $+0.011 \%$ CTX; T6, T1 $+0.021 \%$ CTX; T7, commercial diet with $40 \%$ corn. Although ADFI, and egg quality were not affected by dietary treatments, the egg production was higher $(P<0.05)$ in diet supplemented with $0.021 \%$ colorant than diet with $50 \%$ corn, and diet supplemented $0.011 \%$ colorant. Yolk color in layers fed the diet contained $10 \%$ DDGS was higher $(P<0.05)$ than the layers fed the T1 diet, and the diet with 5\% DDGS. Yolk color score was linearly improved $(P<0.05)$ when the diet supplemented with $0.011 \%$, and $0.021 \%$ CTX. Higher yolk color score was also observed $(P<0.05)$ when layers fed commercial diet compared with control diet, and the diet with higher natural xanthophylls. In conclusion, egg production and yolk color were improved when layers fed diet supplemented with colorant.
\end{abstract}

Keywords: canthaxanthin, egg production, egg quality, egg yolk color, laying hens

\section{Introduction}

Egg yolk color is a major concern to consumers and greatly affects their purchasing behavior (De-Groote, 1970; Fletcher, 1999). Although xanthophylls containing diet does not provide higher nutrition levels, enhancements are observed in pigmentation of egg yolk (Bortolotti et al., 2003; Na et al., 2004; Wang et al., 2007).

High-energy concentrated feeds having low pigment content, which must be supplemented with pigments, are usually used industrially (Vargas et al., 1998). Dried distillers' grains (DDGS) is one of the most important ingredients of laying hen feed contains lutein, zeaxanthin, which are the main xanthophylls in egg yolks (Karunajeeva et al., 1984; Bailey \& Chen, 1989). The activity of the xanthophylls is limited by their relative instability to high temperature and light. However, Williams et al. (1963) reported that natural sources of such pigments were more efficiently used than were the purified forms.

About 6-8 mg of xanthophylls/ $\mathrm{kg}$ of feed is required to produce an egg color that is acceptable to consumers (Avila et al., 1990). Even this small quantity of pigment represents a considerable cost for egg producers (Williams, 1992). Several researches have been carried out to seek improvements of pigmentation efficiency (Middendorf et al., 1980; Marusich \& Baurenfeind, 1981). The synthetic pigment canthaxanthin (CTX) is found 1.5-5 times as potent as natural xanthophylls for the pigmentation of egg yolk (Akiba et al., 2000). Presently, one type of chemically isomerized marigold with $10 \%$ of xanthophylls as CTX in practical layer diet (maize-wheat-soybean) was supplemented to evaluate the effects of CTX on egg production, egg quality and egg-yolk color, compared to a diet containing a high content of xanthophyll.

\section{Materials and Methods}

All birds used in this trial were handled in accordance with guidelines set forth by the Dankook University Committee on Laboratory Animal Care. 


\subsection{Experimental Design, Animals, and Diets}

A total of 280 ISA Brown laying hens were randomly assigned to 1 of 7 dietary treatments in an experiment that was conducted with hens from 36 to $40 \mathrm{wk}$ of age. Dietary treatments were: T1, negative control $(30 \%$ corn $+20 \%$ wheat); T2, diet with 50\% corn; T3, diet with 5\% DDGS; T4, diet with 10\% DDGS; T5, T1+0.011\% CTX; T6, T1 $+0.021 \%$ CTX (Synthetic canthaxanthin beadlets (CarophyllRed, Lisbon, Portugal) with 10\% canthaxanthin); T7, commercial diet with $40 \%$ corn. Hens were weighed individually at the onset of the experiment and then assigned to treatments in a randomized block design based on house location. There were 4 replicates for each treatment, with 5 adjacent cages $(2$ hens/cage, 38.1 -cm width $\times 50$-cm length $\times 40$-cm height) representing a replicate. The hens were housed in a windowless and temperature controlled room that was maintained at $20^{\circ} \mathrm{C}$ with a daily lighting schedule of 17L:7D. There was 1 empty cage between every 5 cages. Hens were allowed to water and feed ad libitum through the nipple of an automatic drinker and a common trough feeder, respectively. The experimental diets (Table 1) were formulated in accordance with recommendations in the breeder's manual for ISA Brown hens and to meet the nutrient recommendations (NRC, 1994), and were provided in mesh form. Dietary calcium $(\mathrm{Ca})$, phosphorus $(\mathrm{P})$, crude protein, lysine and methionine were analysed according to the procedures described by the AOAC (1995). Dietary Ca was assayed by atomic absorption spectrophotometry after wet ash procedures and $\mathrm{P}$ was determined by colorimetry. Lysine content was measured using an amino acid analyzer (Beckman 6300, Beckman Coulter, Inc., Fullerton, California, U.S.A.) after 24-h $6 \mathrm{~N}$-HCl hydrolysis at $110^{\circ} \mathrm{C}$ (AOAC, 1995). Gross energy was determined by using a Parr 6100 oxygen bomb calorimeter (Parr instrument Co., Moline, Illinois, U.S.A.). Before the beginning of the experiment, 29-wk-old hens were purchased and provided with a basal diet for a 7-wk adjustment period, and birds not laying well were replaced.

Table 1. Compositions of experimental diets1

\begin{tabular}{|c|c|c|c|c|c|c|c|}
\hline Items & T1 & $\mathrm{T} 2$ & T3 & T4 & T5 & T6 & T7 \\
\hline \multicolumn{8}{|l|}{ Ingredients, \% } \\
\hline Corn & 30.00 & 50.00 & 30.00 & 30.00 & 30.00 & 30.00 & 40.00 \\
\hline Wheat & 20.00 & - & 15.00 & 10.00 & 20.00 & 20.00 & 10.00 \\
\hline Grain sorghum & 10.00 & 10.00 & 10.00 & 10.00 & 10.00 & 10.00 & 3.00 \\
\hline Soybean meal (CP 46\%) & 19.20 & 21.20 & 20.70 & 20.20 & 19.19 & 19.18 & 19.20 \\
\hline Wheat bran & 7.00 & 5.00 & 5.00 & 5.00 & 7.00 & 7.00 & 7.00 \\
\hline DDGS & - & - & 5.00 & 10.00 & - & - & 7.00 \\
\hline Tallow & 4.40 & 4.40 & 4.90 & 5.40 & 4.40 & 4.40 & 4.40 \\
\hline Dicalcium phosphate & 1.30 & 1.30 & 1.30 & 1.30 & 1.30 & 1.30 & 1.30 \\
\hline Limestone & 7.50 & 7.50 & 7.50 & 7.50 & 7.50 & 7.50 & 7.50 \\
\hline Salt & 0.30 & 0.30 & 0.30 & 0.30 & 0.30 & 0.30 & 0.30 \\
\hline DL-Methionine (50\%) & 0.10 & 0.10 & 0.10 & 0.10 & 0.10 & 0.10 & 0.10 \\
\hline Vitamin premix ${ }^{2}$ & 0.10 & 0.10 & 0.10 & 0.10 & 0.10 & 0.10 & 0.10 \\
\hline Trace mineral premix & 0.10 & 0.10 & 0.10 & 0.10 & 0.10 & 0.10 & 0.10 \\
\hline Colorant & & & & & 0.011 & 0.021 & \\
\hline \multicolumn{8}{|l|}{ Calculated value, $\%$} \\
\hline $\mathrm{AME}, \mathrm{kcal} / \mathrm{kg}$ & 2,934 & 2,956 & 2,979 & 2,975 & 2,940 & 2,938 & 2,904 \\
\hline $\mathrm{CP}$ & 15.60 & 15.65 & 15.65 & 15.65 & 15.65 & 15.65 & 15.65 \\
\hline Lys & 0.83 & 0.85 & 0.84 & 0.85 & 0.84 & 0.84 & 0.82 \\
\hline Met + Cys & 0.94 & 0.93 & 0.93 & 0.92 & 0.92 & 0.92 & 0.93 \\
\hline $\mathrm{Ca}$ & 3.35 & 3.40 & 3.40 & 3.40 & 3.37 & 3.37 & 3.40 \\
\hline$\overline{\mathrm{P}}$ & 0.65 & 0.67 & 0.66 & 0.66 & 0.66 & 0.66 & 0.65 \\
\hline \multicolumn{8}{|l|}{ Chemical analysis value, $\%$} \\
\hline $\mathrm{AME}, \mathrm{kcal} / \mathrm{kg}$ & 2,945 & 2,966 & 2,960 & 2,947 & 2,955 & 2,950 & 2,900 \\
\hline Crude protein & 15.69 & 15.70 & 15.65 & 15.70 & 15.70 & 15.68 & 15.68 \\
\hline Lys & 0.92 & 0.93 & 0.91 & 0.90 & 0.91 & 0.90 & 0.91 \\
\hline $\mathrm{Ca}$ & 3.43 & 3.50 & 3.47 & 3.48 & 3.45 & 3.44 & 3.50 \\
\hline $\mathrm{P}$ & 0.66 & 0.67 & 0.65 & 0.66 & 0.64 & 0.62 & 0.66 \\
\hline
\end{tabular}

T1, negative control (30\% corn $+20 \%$ wheat); T2, positive control (50\% corn); T3, $5 \%$ DDGS; T4, $10 \%$ DDGS; T5, T1 $+0.011 \%$ CTX; T6, T1 $+0.021 \%$ CTX; T7, commercial feed ( $40 \%$ corn). Provided per kilogram of diet is 125,000 IU of vitamin A; 2,500 IU of vitamin D3; $10 \mathrm{mg}$ of vitamin E; $2 \mathrm{mg}$ of vitamin K3; $1 \mathrm{mg}$ of vitamin B1; 5 $\mathrm{mg}$ of vitamin B2; $1 \mathrm{mg}$ of vitamin B6; $15 \mathrm{mg}$ of vitamin B12; $500 \mathrm{mg}$ of folic acid; 35,000 mg ofniacin; 10,000 $\mathrm{mg}$ of Ca-pantothenate; and $50 \mathrm{mg}$ of biotin. Provided per kilogram of diet is $8 \mathrm{mg}$ of $\mathrm{Mn}\left(\right.$ as $\left.\mathrm{MnO}_{2}\right) ; 60 \mathrm{mg}$ of $\mathrm{Zn}$ (as $\left.\mathrm{ZnSO}_{4}\right) ; 5 \mathrm{mg}$ of $\mathrm{Cu}\left(\right.$ as $\mathrm{CuSO}_{4} \cdot 5 \mathrm{H}_{2} \mathrm{O}$ ); $40 \mathrm{mgof} \mathrm{Fe}\left(\right.$ as $\mathrm{FeSO}_{4} \cdot 7 \mathrm{H}_{2} \mathrm{O}$ ); $0.3 \mathrm{mg}$ of $\mathrm{Co}\left(\right.$ as $\mathrm{CoSO}_{4} \cdot 5 \mathrm{H}_{2} \mathrm{O}$ ); $1.5 \mathrm{mg}$ of I (as KI); and $0.15 \mathrm{mg}$ of $\mathrm{Se}\left(\right.$ as $\left.\mathrm{Na}_{2} \mathrm{SeO}_{3} \cdot 5 \mathrm{H}_{2} \mathrm{O}\right)$. 


\subsection{Sampling and Measurements}

Daily records of egg production and weekly records of feed consumption were maintained. Egg production was expressed as average hen day production. A total of 20 saleable eggs (no shell defects, cracks, or double yolks) were randomly collected at 17:00 pm from each treatment ( 5 per replicate, $\mathrm{n}=20$ ) on a weekly basis and used to determine the egg quality at 20:00 pm the same day. The specific gravity of eggs was determined by using the saline flotation method of Hempe et al. (1998). Salt solutions were made in incremental concentrations of 0.005 in the range from 1.065 to 1.120. Eggshell breaking strength was evaluated by using an eggshell force gauge (Robotmation. Co., Ltd., Japan). Eggshell thickness was measured on the large end, equatorial region, and small end, respectively, using a dial pipe gauge (Ozaki MFG. Co., Ltd., Japan). Finally, egg weight, egg yolk color, and Haugh units (HU) were evaluated using an egg multitester (Touhoku Rhythm. Co., Ltd., Japan).

\subsection{Statistical Analysis}

All data were subjected to the statistical analysis as a randomized complete block design using the GLM procedures (SAS Inst. Inc., Cary, NC). The initial BW was used as a covariate for ADFI. Differences among treatment means were determined using the Duncan's multiple range test, with a $P<0.05$ indicating a significance.

\section{Results}

\subsection{Egg Production}

The egg production was higher $(\mathrm{P}<0.05)$ in $\mathrm{T} 6$ treatment $(\mathrm{T} 1+0.021 \% \mathrm{CTX})$ than that of $\mathrm{T} 2(50 \%$ corn $)$ and $\mathrm{T} 5$ (T1+0.011\% CTX) treatments (Table 2).

Table 2. Effect of dietary raw material and colorant on egg production in layers

\begin{tabular}{llllllllll}
\hline Items, \% & T1 & T2 & T3 & T4 & T5 & T6 & T7 & T1 & P value \\
\hline Egg production & $98.6^{\mathrm{ab}}$ & $97.4^{\mathrm{b}}$ & $98.6^{\mathrm{ab}}$ & $97.9^{\mathrm{ab}}$ & $97.4^{\mathrm{b}}$ & $99.0^{\mathrm{a}}$ & $98.2^{\mathrm{ab}}$ & 0.4 & 0.035
\end{tabular}

T1, negative control (30\% corn $+20 \%$ wheat); T2, positive control (50\% corn); T3, 5\% DDGS; T4, 10\% DDGS; T5, T1 $+0.011 \%$ CTX; T6, T1+0.021\% CTX; T7, commercial feed (40\% corn). SE, Standard error. Treatment values followed by same alphabet do not differ significantly at $P=0.05$.

\subsection{ADFI}

There's no difference $(P>0.05)$ was observed in ADFI by dietary treatments (Table 3$)$.

Table 3. Effect of dietary raw material and colorant on ADFI in layers

\begin{tabular}{llllllllll}
\hline Items & T1 & T2 & T3 & T4 & T5 & T6 & T7 & SE & P value \\
\hline ADFI, g & 135 & 137 & 135 & 136 & 135 & 136 & 135 & 1 & 0.657 \\
\hline
\end{tabular}

T1, negative control (30\% corn $+20 \%$ wheat); T2, positive control (50\% corn); T3, 5\% DDGS; T4, 10\% DDGS; T5, T1+0.011\% CTX; T6, T1+0.021\% CTX; T7, commercial feed (40\% corn). SE, Standard error.

\subsection{Egg Quality}

During the experiment, no effects $(P>0.05)$ of dietary treatments were observed on egg gravity, strength, yolk height, shell color, haugh unit, and shell thickness (Table 4). 
Table 4. Effect of dietary raw material and colorant on egg quality in layers

\begin{tabular}{llllllllll}
\hline Items & $\mathrm{T} 1$ & $\mathrm{~T} 2$ & $\mathrm{~T} 3$ & $\mathrm{~T} 4$ & $\mathrm{~T} 5$ & $\mathrm{~T} 6$ & $\mathrm{~T} 7$ & $\mathrm{SE}$ & P value \\
\hline Gravity & 1.10 & 1.10 & 1.10 & 1.10 & 1.10 & 1.10 & 1.10 & 0.00 & 0.722 \\
Strength $\left(\mathrm{kg} / \mathrm{cm}^{2}\right)$ & 3.88 & 3.85 & 3.97 & 3.85 & 3.83 & 3.81 & 3.84 & 0.05 & 0.214 \\
Weight $(\mathrm{g})$ & 60.3 & 60.8 & 60.6 & 61.0 & 60.5 & 60.6 & 60.5 & 0.2 & 0.325 \\
Height $(\mathrm{mm})$ & 8.2 & 8.1 & 8.1 & 8.0 & 8.0 & 8.1 & 8.2 & 0.1 & 0.841 \\
Shell color & 11.10 & 11.5 & 11.2 & 11.5 & 11.2 & 11.3 & 11.2 & 0.2 & 0.651 \\
Haugh unit & 90.1 & 89.0 & 89.6 & 88.9 & 89.1 & 89.5 & 89.8 & 0.4 & 0.252 \\
Shell thickness (mm) & 39.7 & 39.3 & 39.8 & 38.6 & 39.2 & 38.6 & 39.7 & 0.5 & 0.698
\end{tabular}

T1, negative control (30\% corn $+20 \%$ wheat); T2, positive control ( $50 \%$ corn); T3, $5 \%$ DDGS; T4, $10 \%$ DDGS; T5, T1+0.011\% CTX; T6, T1+0.021\% CTX; T7, commercial feed (40\% corn). SE, Standard error.

Table 5. Effect of dietary raw material and colorant on yolk color in layers

\begin{tabular}{llllllllll}
\hline Items & $\mathrm{T} 1$ & $\mathrm{~T} 2$ & $\mathrm{~T} 3$ & $\mathrm{~T} 4$ & $\mathrm{~T} 5$ & $\mathrm{~T} 6$ & $\mathrm{~T} 7$ & $\mathrm{SE}$ & P value \\
\hline Yolk color & $4.8^{\mathrm{e}}$ & $5.4^{\mathrm{de}}$ & $5.0^{\mathrm{e}}$ & $5.9^{\mathrm{d}}$ & $7.6^{\mathrm{b}}$ & $9.7^{\mathrm{a}}$ & $6.5^{\mathrm{c}}$ & 0.19 & 0.024 \\
\hline
\end{tabular}

T1, negative control (30\% corn $+20 \%$ wheat); T2, positive control (50\% corn); T3, 5\% DDGS; T4, $10 \%$ DDGS; T5, T1+0.011\% CTX; T6, T1+0.021\% CTX; T7, commercial feed (40\% corn). SE, Standard error.

\subsection{Yolk Color}

Laying hens fed the T6 diet had the highest $(P<0.05)$ yolk color among dietary treatments, while yolk color in T4 treatment was higher $(P<0.05)$ than those in T1 and T3 treatments. Yolk color score was increased $(P<0.05)$ when the diet supplemented with colorant compared to other diets, and the effect was improved $(P<0.05)$ by increasing the content of the colorant. Higher $(P<0.05)$ yolk color score was also observed when layers fed commercial diet compared to $\mathrm{T} 1, \mathrm{~T} 2, \mathrm{~T} 3$, and $\mathrm{T} 4$ treatments.

\section{Discussion}

The present study demonstrates that the dietary raw material and CTX had no effects on feed consumption and egg quality characteristics such as egg gravity, shell-breaking strength, shell thickness, and Haugh units. These data corroborate the results obtained with no feed consumption (Khaton et al., 1999; Hasin et al., 2006), egg gravity (Saha et al., 1999; Hasin et al., 2006) in hens fed a diet enriched in CTX.

Presently, egg production was higher $(\mathrm{P}<0.05)$ in a diet with $0.021 \%$ CTX than a diet with $50 \%$ corn, and a diet supplemented with $0.011 \%$ CTX. These results differ from the previous findings of no effect of colorant on egg production (Garcia et al., 2002; Soto-Salanova, 2003; Kanda et al., 2011).

Pigmentation of egg yolks is influenced mostly by layer diet (Colin et al., 2004) and DDGS is a rich source of xanthophylls (Bailey \& Chen, 1989). Natural xanthophyll is well-absorbed by hen intestinal cells (Gouveia et al., 1996) and is transferred to the yolk (Donald \& William, 2002) after being released into the circulatory system (Salma et al., 2007). However, in natural products, xanthophylls are unstable and effective levels may decline as a result of oxidation during prolonged storage. Previous studies have also reported that ifferent forms of xanthophylls have different deposition rate in eggs (Bowen et al., 2002). The discussion continues about whether free or esterified xanthophylls have higher bioavailability, not only with repect to animal feed, but also in view of human dietary supplements that contain free or esterified forms of lutein (Bowen et al., 2002). The zeaxanthin content of corn deposited in the yolk can be $7 \%$, while the content of some synthetic products such as $\beta$-apo-8-carotenoic acid ethyl ester and CTX can reach 34\% (Roche Vitamins \& Fine Chemicals, 1988).

In our study, we found that yolk color was enhanced by a diet containing $10 \%$ DDGS, which was agree with an earlier study reported that intact yolk color was enhanced quickly with a diet containing $10 \%$ DDGS after about 2 months when 5\% DDGS was fed to birds previously fed a corn-soybean meal with no additional pigments 
(Roberson et al., 2005). Also, the present observation that yolk color scores linearly increased with an increase in the concentration of dietary CTX $(0.011 \%-0.021 \%)$ in laying hens fed a low-carotenoid diet is consistent with the finding that the yolk color score increased with increasing percentages of dietary paprika (Niu et al., 2008).

This research demonstrated that CTX could be incorporated into egg yolks at $0.011 \%$ and $0.021 \%$, and that a diet with $10 \%$ DDGS also improves egg yolk color compared with a diet low in xanthophylls.

\section{Conclusion}

In conclusion, it can be concluded that dietary CTX supplementation at level of $0.021 \%$ can affect egg production and improve the pigmentation of egg yolk. However, it is still necessary to conduct more researches of CTX in laying hens, due to the limited data on the mechanism of pigmentation in layers.

\section{Acknowledgment}

The authors would like to acknowledge the financial assistance (No. PJ0081212012 of Bio-Green 21) provided by the Rural Development Administration of Korea.

\section{References}

Akiba, Y., Sato, K., Takahashi, K., Takahashi, Y., Furuki, A., Konashi, S., ... Nagao, H. (2000). Pigmentation of egg yolk with yeast phaffia rhodozyma containing high concentration of astaxanthin in laying hens fed on a low-carotenoid diet. J. Poultry. Sci., 3, 77-85.

Avila, E., Shimada, A., Llamas, S., \& Otros aditivos, G. (1990). In Anabo'licos y Aditivos en la Produccio'n Pecuaria, 1st ed. Consultores en Produccio'n Animal, S.C., Me'xico, 239-250.

Bailey, C. A., \& Chen, B. H. (1989). Chromatographic analyses of xanthophyl in egg yolks from laying hens fed Turf Bermudagrass (Cynodon dactylon) meal. J. Food. Sci., 54, 584-586. http://dx.doi.org/10.1111/j.1365-2621.1989.tb04658.x

Bortolotti, G. R., Negro, J. J., Surai, P. F., \& Prieto, P. (2003). Carotenoids in eggs and plasma of red-legged partridges: effects of diet and reproductive output. Physiol. Biochem. Zool., 76, 367-374. http://dx.doi.org/10.1086/375432

Bowen, P. E., Herbst-Espinosa, S. M., Hussain, E. A., \& Stacewicz-Sapuntzakis, M. (2002). Esterification does not impair lutein bioavailability in humans. J. Nutr., 132, 3668-3673.

Colin, G. S., George, B., \& Ensminger, M. E. (2004). Poultry Science (4th ed). New Jersey: Pearson Prentice Hall, Upper Saddle River.

De-Groote, G. (1970). Research on egg yolk pigmentation and itspractical application. World's Poult. Sci. J., 20 , 435-441. http://dx.doi.org/10.1079/WPS19700005

Donald, D. B., \& William, D. W. (2002). Commercial Chicken Meat and Egg production (5th ed). USA: Kluwer Academic Publishers.

Fletcher, D. L. (1999). Broiler breast meat color variation, pH, and texture. Poult. Sci., 78, 1323-1327.

Garcia, E. A., Mendes, A. A., Pizzolante, C. C., Goncalves, H. C., Oliveira, R. P., \& Silva, M. A. (2002). Effect of canthaxathin levels on performance and egg quality of laying hens. Braz. J. Poultry. Sci., 4, 1-4.

Gouveia, L., Veloso, V., Reis, A., Fernandes, H., Novais, J., \& Empis, J. (1996). Chlorella Vularis used to colour $\begin{array}{llllll}\text { egg yolk. S. Sci. Food. } & \text { Agr., } & 70, & 167-172 .\end{array}$ http://dx.doi.org/10.1002/(SICI)1097-0010(199602)70:2<167::AID-JSFA472>3.0.CO;2-2

Hasin, B. M., Ferdaus, A. J. M., Islam, M. A., Uddin, M. J., \& Islam, M. S. (2006). Marigold and orange skin as egg yolk color promoting agents. Int. J. Poultry. Sci., 5, 979-987. http://dx.doi.org/10.3923/ijps.2006.979.987

Hempe, J. M., Lauxen, R. C., \& Savage, J. E. (1998). Rapid determination of egg weight and specific gravity using a computerized data collection system. Poult. Sci., 67, 902-907. http://dx.doi.org/10.3382/ps.0670902

Kanda, L., Koh-en, Y., Tsutomu, K., \& Keiko, S. (2001). Enhancement of yolk color in raw and boiled egg yolk with lutein from marigold flower meal and marigold flower extract. J. Poultry. sci., 48, 25-32.

Karunajeeva, H., Hughes, R. S., McDonald, M. W., \& Shenstone, F. S. (1984). A review of factors influencing pigmentation of egg yolks. World's Poult. Sci. J., 40, 52-65. http://dx.doi.org/10.1079/WPS19840006

Karunajeewa, H. (1980). The deposition of synthetic oxycarotenoids in egg yolks. World. Poult. Sci. J., 36, 219-222. http://dx.doi.org/10.1079/WPS19800011 
Khaton, A., Ali, M. A., \& Dingel, J. G. (1999). Comparison of the nutritivevalue for laying hens of diets containing azolla (Azolla pinata) based on formulation using digestible protein anddigestible amino acid. Anim. Feed Sci. Technol., 81, 43-56. http://dx.doi.org/10.1016/S0377-8401(99)00071-1

Marusich, W. L., \& Baurenfeind, J. C. (1981). Oxycarotenoids in poultry feeds. In J. C. Baurenfeind (Ed.), Carotenoids as Colorants and Vitamin a Precursors (pp. 319-462). New York: Academic Press.

Middendorf, D. F., Childs, G. R., \& Cravens, W. W. (1980). Variation in the biological availability of xanthophyll within and among generic sources. Poult. Sci., 59, 1460-1470. http://dx.doi.org/10.3382/ps.0591460

Na, J. C., Song, J. Y., Lee, B. D., Lee, S. J., Lee, C. Y., \& An, G. H. (2004). Effect of polarity on absorption and accumulation of carotenoids by laying hens. Anim. Feed. Sci. Technol., 117, 305-315. http://dx.doi.org/10.1016/j.anifeedsci.2004.08.012

Niu, Z., Fu, J., Gao, Y., \& Liu, F. (2008). Influence of paprika extract supplement on egg quality of laying hens fed wheat-based diet. Int. J. Poultry. Sci., 7, 887-889. http://dx.doi.org/10.3923/ijps.2008.887.889

NRC. (1994). Nutrient Requirements of Poultry. 9th rev. Ed. Washington DC: Natl. Acad. Press.

Roberson, K. D., Kalbfleisch, J. L., Pan, W., \& Charbeneau, R. A. (2005). Effect of corn distiller's dried grains with solubles at various Levels on performance of laying hens and egg yolk color. Int. J. Poultry. Sci., 4, 44-51. http://dx.doi.org/10.3923/ijps.2005.44.51

Roche vitamins and fine chemicals. (1988). Egg yolk pigmentation with carophyll (3rd ed) (p. 1218). Switzerland: Hoffmann-La Roche. Ltd., Basel.

Saha, P. K., Chowdhury, S. D., \& Saha, S. K. (1999). Replacement value of two Bangladeshi varieties of yellow corn for wheat in the diet of diet of laying chicken. A. A. J. Ani. Sci., 12, 776-782.

Salma, U. A., Miah, G., Tareq, K. M. A., Maki, T., \& Tsujii, H. (2007). Effects of dietary Rhodobacter capsulatus on egg-yolk cholesterol and laying hen performance. Poultry. Sci., 86, 714-719.

Soto-Salanova, M. F. (2003). Natural pigments: practical experiences. In P. C. Garnsworthy, J. Wiseman (Eds.), Recent Advances in Animal Nutrition. Nottingham. UK.: Nottingham University Press.

Vargas, F. D., Lo'pez, O. P., \& González, E. A. (1998). Effects of sunlight illumination of marigold flower meals on egg yolk pigmentation. J. Agric. Food, 46, 698-706. http://dx.doi.org/10.1021/j99702454

Wang, Y. M., Connor, S. L., Wang, W., Johnson, E. J., \& Connor, W. E. (2007). The selective retention of lutein, meso-zeaxanthin and zeaxanthinin the retina of chicks fed a xanthophylls-free diet. Exp. Eye. Res., 84, 591-598. http://dx.doi.org/10.1016/j.exer.2006.11.013

Williams, W. D. (1992). Origin and impact of color on consumer preference for food. J. Poultry. Sci., 71, 744-746. http://dx.doi.org/10.3382/ps.0710744

Williams, W. P., Davies, R. E., \& Couch, J. R. (1963). The utilization of carotenoids by the hen and chick. Poult. Sci., 42, 691-699. http://dx.doi.org/10.3382/ps.0420691 